\title{
PHENOTYPIC CHARACTERIZATION OF PSEUDOMONAS BACTERIA ISOLATED FROM POLLUTED SITES OF OSTRAVA, CZECH REPUBLIC
}

\section{FENOTYPOVÁ CHARAKTERISTIKA BAKTERII PSEUDOMONAS IZOLOVANÝCH Z KONTAMINOVANÝCH OBLASTÍ OSTRAVY, ČESKÁ REPUBLIKA}

\author{
Hana VOJTKOVÁ ${ }^{1}$, Romana JANULKOV' ${ }^{2}$, Pavla ŠVANOVÁ ${ }^{3}$ \\ ${ }^{1}$ Mgr., Ph.D., Institute of Environmental Engineering, Faculty of Mining and Geology, VŠB - \\ Technical University of Ostrava, 17. listopadu 15, Ostrava, tel. (+420) 597323541 \\ e-mail hana.vojtkova@vsb.cz \\ ${ }^{2}$ Bc., Institute of Environmental Engineering, Faculty of Mining and Geology, VŠB - Technical \\ University of Ostrava, 17. listopadu 15, Ostrava, tel. (+420) 597323541 \\ e-mail romana.janulkova@seznam.cz \\ ${ }^{3}$ Bc., Institute of Environmental Engineering, Faculty of Mining and Geology, V̌̌ B - Technical \\ University of Ostrava, 17. listopadu 15, Ostrava, tel. (+420) 597323541 \\ e-mail pavla.svanova@centrum.cz.
}

\begin{abstract}
The environment of industrial cities is usually exposed to extreme impacts of anthropogenic contamination originating from fossil fuel combustion, road traffic, industry, ore mining and dressing. The degradation potential of contaminated soils greatly depends on the diversity and function of the microbial ecosystem in the given locality; in individual communities, it is possible to diagnose identical as well as different characteristics of specific bacterial strains. From the real soil samples within the City of Ostrava, namely localities strained by industrial activities, new strains were isolated and compared on the grounds of biochemical identification results using a modern system of BIOLOG MicroStation. Basic characteristics of the new isolated strains are stated, which document their phenotypic diversity not only on the level of the Pseudomonas genus but also on the level of the individual species. The differences in the physiological parameters of isolated strains are attributed to the capacities of the soil microorganisms to adapt to the polluted environment conditions. The paper offers an overview of the significance of phenotypic characterization for identification of microorganisms and their correct taxonomic classification.

Abstrakt

Životní prostředí v průmyslových městech je obvykle vystaveno vysokým vlivům antropogenní kontaminace pocházející zejména ze spalování fosilních paliv, silniční dopravy, průmyslové činnosti, těžby a zpracování rud. Degradační potenciál kontaminovaných půd je výrazně ovlivněn diverzitou a funkcí mikrobiálního ekosystému dané lokality, $\mathrm{v}$ jednotlivých společenstvech lze diagnostikovat shodné i rozdílné vlastnosti specifických bakteriálních kmenů. Z reálných půdních vzorků z území města Ostravy, z lokalit zatížených průmyslovou činností, byly izolovány nové bakteriální kmeny, které byly srovnávány na základě výsledků biochemické identifikace pomocí moderního systému BIOLOG MicroStation. U nově izolovaných kmenů jsou uvedeny jejich základní charakteristiky, které dokládají fenotypovou variabilitu nejen na úrovni rodu Pseudomonas, ale také na úrovni jednotlivých druhů. Rozdíly ve fyziologických parametrech izolovaných kmenů jsou dány do souvislosti se schopností adaptace půdních mikroorganismů na podmínky znečištěného prostředí. Článek podává přehled o významu fenotypové charakteristiky pro identifikaci mikroorganismů a jejich správného taxonomického řazení.
\end{abstract}

Key words: identification, phenotypization, biochemical properties, Pseudomonas sp. 


\section{INTRODUCTION}

Microorganisms make a significant constituent of the biosphere and the knowledge of their biological properties is the grounds of their practical utilization, including biotechnological industrial applications. Newly isolated microorganisms are described using a whole number of identification methods, the precondition of which is an accurate characteristic of the phenotypic properties of the microorganisms. If a taxon is described well and in a sufficient detail, within the systematics the taxonomic classification of an unknown organism means very important and rich information on the morphological, biochemical, pathogenic, antigenic and other properties specifying the taxon in question. The identification as well as own classification is then carried out by identifying a value being a particular characteristic in a specific organism. A possible identification method is a dichotomous key, which is a tool always giving two choices in each step and is predominantly applied to identify plants and animals, where the classification is made on the basis of a value of one key feature. Despite certain difficulties such keys have already been set up for bacteria as well. However, the most substantial difficulty is connected with the occurrence of a range of exceptions to the rule at a given feature value.

Sorting the newly identified strain into a taxon, the procedure is usually based on the agreement of classification features. The values of the features in bacteria are the probability quantities, which carries along a numerical identification, i.e. the numerical evaluation of a similarity between the classified units and the subsequent arrangement of the units, into a taxon on the grounds of the agreed size.

Another important method is a mathematical construction of an identification feature, where a mathematical apparatus must be used to determine the decisive and significant feature. This procedure is advantageous in reducing the number of required identification tests but disadvantageous because of the difficulties in identifying a strain due to the occurrence of a whole number of aberrant features.

In phenotypization of organisms, the most frequently applied method is the probability method which is based on the determination of probability of positive results of individual tests for the representatives of the individual taxons; the results of a known and unknown strain are compared. The outcome is an identification expressed as probability on the grounds of which the unknown strain is attributed to a systematic category and its identification is based on the properties of the given taxon. The determination method of the overall similarity of an unknown strain with a polythetically known organisms, their groups or hypothetically mean organisms representing a given group is based on the similarity of $90 \%$ of the features for identification at the level of a species and $70 \%$ at the level of a genus $[1,2]$.

\section{BIOCHEMICAL TESTS}

In determining biochemical properties of microorganisms, biochemical manifestations are usually detected on the basis of the metabolic products arising during physiological reactions of live strains. Among the basic biochemical reactions observed in the majority of microorganisms there are the ability of fermentation of diverse carbohydrates, capacity to utilize various substrates as the sources of carbon and energy, hydrolysis of particular substrates, activity of relevant enzymes, production of specific metabolites, ability of haemolysis, hydrolysis, colour reactions and others [3].

A number of producers currently supply standard kits of biochemical tests, not only including the stated tests but also identification diagnostic tests focusing on the verification of properties of a particular group of microorganisms (HiMedia Laboratories ${ }^{\mathrm{TM}}$, Mumbai, India).

A certificate of an enzymatic activity product of a given microorganism is usually carried out on the grounds of a calorimetric reaction, when the presence of a suitable indicator changes the colour of the original substrate due to the accumulation of metabolites produced by microorganisms (thanks to an easily identifiable change in the colour, the test kit is also referred to as the "multicolour kit").

Biochemical tests are mostly carried out in precisely defined liquid media in test tubes or slant agar, or using discs and strips on solid media in Petri dishes. When assessing the results of metabolic reactions, formation of characteristic final products is also observed, such as gas leaks, production of a precipitate or fluidification of the medium. The obtained test results are compared with the values in the diagnostic table, and the overall conclusions are drawn on the basis of common data examining the macroscopic as well as microscopic characteristics.

However, in practical applications, problems occur with ambiguous identification of microorganisms on the basis of biochemical tests as microorganisms isolated from the natural environment mostly lack absolutely identical genetic properties with the collection strains, which may also be registered in the results of the biochemical assays. 


\section{MATERIAL AND METHODS}

\subsection{Isolation and identification of Pseudomonas strains from soil samples}

The genus of Pseudomonas is very heterogeneous and represents an environmentally important group of bacteria which includes gram-negative, aerobic, motile, rod-like bacteria with almost cosmopolitan distribution and which are known for their high metabolic versatility thanks to the existence of a wide enzymatic system [4]. The nutrition requirements of the representatives of the Pseudomonas genus are very simple, and thus the bacteria can be found in a range of natural stands such as the soil, natural or waste water, marine environment, air; they have also been isolated from human clinical samples, animal products and live parts of plants and animals [5, 6]. Many bacterial strains Pseudomonas were experimentally confirmed for their good ability of tolerance towards a whole number of organic and inorganic pollutants $[7,8,9,10,11]$.

Samples for the experiment were obtained from various localities within the City of Ostrava, the Czech Republic, where the soils are much burdened by the industry (Table1). The soil samples from the given localities were diluted with sterile distilled water and inoculated into the basic medium Trypton soya agar (HiMedia Laboratories Ltd., Mumbai, India) in Petri dishes. The dishes were incubated for 72 hours at the temperature of $30^{\circ} \mathrm{C}$. Consequently, colonies varying in morphology were selected and inoculated into the selective diagnostic medium CHROMagar ${ }^{\text {TM }}$ Pseudomonas (CHROMagar Microbiology, France). This method helped to isolate the strains of the Pseudomonas genus [11] which were used for further biochemical testing (Fig. 1, Fig. 2).

\subsection{Biochemical testing of the isolated samples}

The basic biochemical identification was found in bacterial differential tests making use of discs for a carbohydrate fermentation test and diagnostic discs to determine nitrate reduction, ONPG test, oxidase test, production of indole, fluidification of gelatin, testing for $\mathrm{H}_{2} \mathrm{~S}$ content (HiMedia Laboratories Ltd., Mumbai, India). For a more accurate phenotypization of the bacterial strains by means of biochemical properties, a method of standard biotypization was used applying the BIOLOG $^{\mathrm{TM}}$ MicroStation system $^{\mathrm{TM}}$ (MicroLog III system, Biolog, USA) which is based on metabolic conversions and enzymatic reactions of a strain with diverse substrates (the reactions proceeded in 96-well microplates with a patented group of biochemical tests [12].

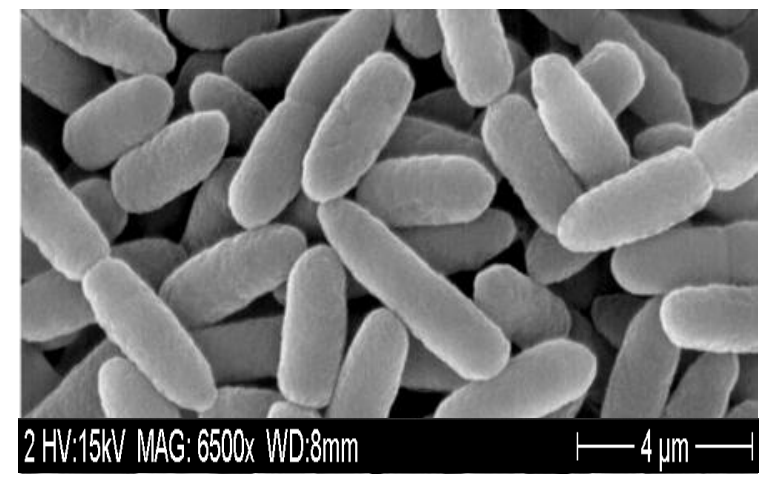

Fig. 1 Bacteria of Pseudomonas fluorescens (author's archive)

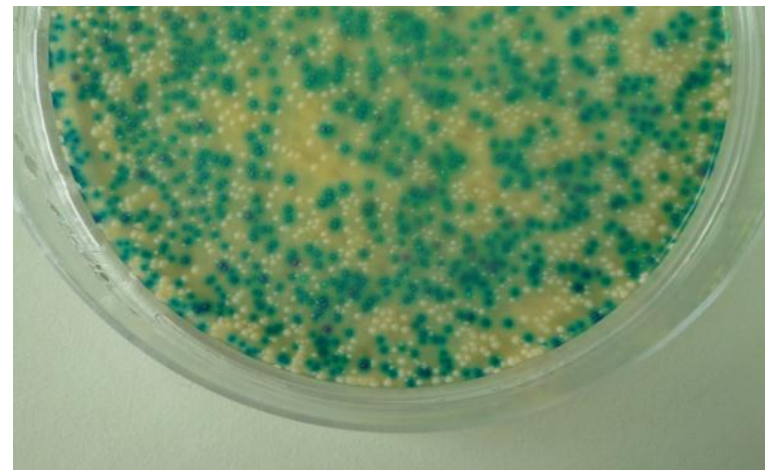

Fig. 2 Blue-green colour of the Pseudomonas colonies on CHROMagar $^{\mathrm{TM}}$

\section{RESULTS AND DISCUSSION}

\subsection{Phenotypic characteristics of the strains}

All the bacterial colonies selected from the medium demonstrated a blue-green colour of the colonies on the differential and selective medium CHROMagar, which proves the systematic affiliation to the genus Pseudomonas sp.

The genus taxonomy is first based on the cell morphology, presence of flagella and assay of the gram-negative type of the cell wall. The key phenotypic feature of the Pseudomonas genus is also the production of pigments, especially pyocyanin, pyoverdine and other fluorescent diffusible pigments (however, there are also species without the capacity of pigmentation). The biochemical identification of the strains was carried out on the basis of fermentation of the carbohydrates using the BIOLOG MicroStation system. Table 1 shows the results of selected tests. 
The results of the phenotypic characteristics based on the physiological, morphological and biochemical tests confirmed the classification of all the identified strains into a single bacterial genus called Pseudomonas.

All the isolated strains were gram-negative, aerobic, with a positive catalase and oxidase, demonstrated an oxidative metabolism and growth at the temperature of $4{ }^{\circ} \mathrm{C}$; only one strain was capable of growth at the temperatures over $41^{\circ} \mathrm{C}$ and the production of fluorescent diffusible pigment of pyocyanin was characteristic only for one strain. The enzymatic activity varied in the individual strains. The outcome of the biochemical characterization coupled with the identification making use of the BIOLOG MicroStation system resulted into the identification of 3 strains as $P$. fluorescens, 2 strains as P. putida and 1 strain as $P$. aeruginosa.

Tab. 1 Basic biochemical properties of 6 isolated strains

\begin{tabular}{|c|c|c|c|c|c|c|}
\hline Characteristics & $\begin{array}{l}P . \text { sp. } \\
\text { (fluorescens) }\end{array}$ & $\begin{array}{l}P . \text { sp. } \\
\text { (putida) }\end{array}$ & $\begin{array}{l}\text { P. sp. } \\
\text { (fluorescens) }\end{array}$ & $\begin{array}{l}P . \text { sp. } \\
\text { (fluorescens) }\end{array}$ & $\begin{array}{l}P . \text { sp. } \\
\text { (putida) }\end{array}$ & $\begin{array}{l}P . \text { sp. } \\
\text { (aeruginosa) }\end{array}$ \\
\hline Locality & $\begin{array}{l}\text { Ostrava- } \\
\text { Černý Př́́kop }\end{array}$ & $\begin{array}{l}\text { Ostrava- } \\
\text { Černý Př́́kop }\end{array}$ & $\begin{array}{l}\text { Ostrava - } \\
\text { Černý Př́kop }\end{array}$ & $\begin{array}{l}\text { Ostrava - } \\
\text { Airport L. J. }\end{array}$ & $\begin{array}{l}\text { Ostrava - } \\
\text { Airport L. J. }\end{array}$ & $\begin{array}{l}\text { Ostrava - } \\
\text { lagoons }\end{array}$ \\
\hline Gram positive & - & - & - & - & - & - \\
\hline Spore forma & - & - & - & - & - & - \\
\hline Growth at $4^{\circ} \mathrm{C}$ & + & + & + & + & + & - \\
\hline Growth at $41^{\circ} \mathrm{C}$ & - & - & - & - & - & + \\
\hline Pyocyanine & - & - & - & - & - & + \\
\hline Fluorescent & + & & + & + & 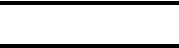 & + \\
\hline Oxidase & + & + & + & + & + & + \\
\hline Denitrification & + & - & - & + & - & + \\
\hline Indol & - & - & - & - & - & - \\
\hline Catalase & + & + & + & + & + & + \\
\hline Fluorescein & - & - & - & - & - & + \\
\hline Simmons test & + & + & + & + & + & + \\
\hline $\mathrm{H}_{2} \mathrm{~S}$ production & - & - & - & - & - & - \\
\hline ONPG test & - & - & - & - & - & - \\
\hline Ribose & + & + & + & + & + & + \\
\hline Xylose & + & + & + & + & + & - \\
\hline Arabinose & + & + & + & + & + & - \\
\hline Glucose & + & + & + & + & + & + \\
\hline Sucrose & + & + & - & + & + & - \\
\hline Galactose & + & - & + & + & - & - \\
\hline Rhamnose & + & - & - & + & - & - \\
\hline Mannose & + & + & + & + & + & - \\
\hline Maltose & - & + & - & - & - & - \\
\hline Lactose & - & - & - & - & - & - \\
\hline Fructose & + & + & + & + & + & + \\
\hline Cellulase & - & - & - & - & - & + \\
\hline Lipase & + & - & - & + & - & + \\
\hline Urease & - & + & - & - & - & - \\
\hline Protease & - & - & - & - & - & + \\
\hline Amylase & - & + & - & - & + & + \\
\hline Pectinase & + & + & + & + & + & - \\
\hline
\end{tabular}

Notes: - negative, + positive

Comparing the isolated strains with published results of the individual strains to date [13, 14], differences in the biochemical activity of the individual strains were confirmed. A classic example is the bacterial strain of $P$. fluorescens, where diverse biotypes of the strain (I - IV) have been gradually reclassified on the grounds of phenotypization studies. Table 2 states major differences. 
Tab. 2 Basic biochemical differences in the biotypes of Pseudomonas fluorescens strain (ABIS Encyclopedia)

\begin{tabular}{|l|c|c|c|c|c|}
\hline & $\begin{array}{c}\text { Fluorescent } \\
\text { diffusible } \\
\text { pigments }\end{array}$ & $\begin{array}{c}\text { Non fluoresc. } \\
\text { diffusible } \\
\text { pigment }\end{array}$ & $\begin{array}{c}\text { Non } \\
\text { fluorescent } \\
\text { non dif. pigm. }\end{array}$ & Lecithinase & Denitrification \\
\hline P. fluorescens biovar 1 & + & - & - & + & - \\
\hline P. fluorescens biovar 2 & + & - & - & - & + \\
\hline P. fluorescens biovar 3 & + & - & - & + & + \\
\hline P. fluorescens biovar 4 & + & - & + & + & + \\
\hline P. fluorescens biovar 5 & + & - & - & - & - \\
\hline
\end{tabular}

\section{CONCLUSIONS}

The results confirmed that the isolation of bacteria making use of standard methods was successful in all the tested bacteria. A correct taxonomic classification of the isolated bacteria to a genus or species required the execution of basic biochemical identification tests. In testing the strains biochemically using the BIOLOG MicroStation system, atypical biochemical properties were also detected in numerous cases, which documents a very high variability and phenotypic (as well as genotypic) diversity within one bacterial strain, thus making space for a possible reclassification of strains, particularly when using other modern methods of gene identification based on the comparison of their genomes.

\section{ACKNOWLEDGEMENTS}

This paper was compiled within the Project of Specific University Research (SGS) no. SP 2012/93. The authors would like to thank the Faculty of Mining and Geology of VŠB - Technical University of Ostrava for the project support.

\section{REFERENCES}

[1] BULL A. T. Microbial Diversity and Bioprospecting. Washington: ASM Press, 2004. ISBN 1-155581$267-8$

[2] MOORE E. R. B, MIHAYLOVA S. A., VANDAMME P., KRICHEVSKY M. I., DIJKSHOORN L. Microbial systematics and taxonomy: relevance for a microbial commons. Research in Microbiology. 2010, vol. 161(6), p. 430-438. ISSN 0923-2508

[3] KLAUSNER, Arthur. New Methods Aid Microbial Identification. Nature Publishing Group, 1988.

[4] BEDNÁR̆ M. \& FRAŇKOVÁ V. \& SCHINDLER J. \& SOUČEK A. \& VÁVRA J. Lékařská mikrobiologie. Praha: Triton, 2009. ISBN 859-4-315-0528-0

[5] REHM B. H. A. (ed.). Pseudomonas. Model organism, pathogen, cell factory. Weinheim: Wiley-VCH Verlag, 2008. ISBN 978-3-527-31914-5

[6] TIMMIS K. N. Pseudomonas putida: a cosmopolitan opportunist par excellence. Environmental Microbiology. 2002, vol. 4(12), p. 779-781. ISSN 1462-2912

[7] CÁNOVAS, D. \& CASES I. \& DE LORENZO V. Heavy metal tolerance and metal homeostasis in Pseudomonas putida as revealed by complete genome analysis. Environmental Microbiology. 2003 , vol. 5(12), p. 1242-1256. ISSN 1462-2912

[8] SEO J. S. \& KEUM Y. S. \& LI Q. X. Bacterial degradation of aromatic compounds. International Journal of Environmental Research and Public Health. 2009, vol. 6(1), p. 278-309. ISSN 1660-4601

[9] SHOEB E. Genetic basic of heavy metal tolerance in bakteria. Ph.D. thesis, University of Karachi, Pakistan, 2006

[10] SPIERS A. J. \& BUCKLING A. \& RAINEY P. B. The causes of Pseudomonas diversity. Microbiology. 2000, vol. 146(10), p. 2345-2350. ISSN 1350-0872

[11] VOJTKOVÁ H. \& JANULKOVÁ R. \& ŠVANOVÁ P. Physiological aspects of metal tolerance in Pseudomonas bacteria isolated from polluted sites in Ostrava, Czech Republic. In $12^{\text {th }}$ International Multidisciplinary Scientific GeoConference SGEM 2012. Bulgaria - Albena: 17.-23. 6. 2012.Conference Proceedings, vol. IV, p. 177-183. ISSN 1314-2704 
[12] BOCHNER B. R. Biolog: Modern Phenotypic Microbial Identification. In MILLER M. J. (ed.) Encyclopedia of Rapid Microbiological Methods, vol. 2. River Grove: Healthcare International Publishing, 2005, p. 55-73. ISBN 1-930114-86-9

[13] GILARDI G. L. Nonfermentative Gram-Negative Rods: Laboratory Identification and Clinical Aspects. New York-Basel: Microbiology Series, 1985. ISBN 0-8247-7370-5

[14] REKHA, V. \& JOHN A. S. \& SHANKAR T. Antibacterial activity of Pseudomonas fluorescens isolated from rhizosphere soil. International Journal of Biological Technology. 2010, vol. 1(3), p. 10-14. ISSN 0976-4313

\section{RESUMÉ}

Znečištění životního prostředí různými polutanty, které vzniká v důsledku antropogenní činnosti, významně ovlivňuje složení a funkci biosféry. Studium struktury mikrobiálních společenstev objasňuje jejich funkci v kontaminovaném prostředí, kde změny $\mathrm{v}$ jejich diverzitě a interakci vypovídají o stabilitě půdního prostředí, o schopnosti biodegradace i o schopnosti regenerace celého ekosystému. Vhodným modelem pro studium těchto vztahů jsou kontaminované půdy v lokalitě Ostravy v místech reálného znečištění průmyslovou výrobou a dopravou. $\mathrm{V}$ experimentech byly zpracovávány vzorky ze tří lokalit s různým stupněm znečištění sedimenty z uměle vybudované vodoteče Černý Př́íkop v Ostravě, půdy kontaminované dopravou z lokality ostravského Letiště Leoše Janáčka a sedimenty pocházející z ostravských lagun, kde byla potvrzena přítomnost několika nových biotypů bakteriálního druhu Pseudomonas, dokládajících kontaminaci širokým spektrem organických i anorganických polutantů.

V článku je zpracována problematika fenotypizace mikroorganismů na základě jejich biochemických charakteristik pomocí moderního systému BIOLOG MicroStation.Výsledky fenotypové identifikace založené na fyziologických, morfologických a biochemických testech potvrdily zařazení všech nově izolovaných kmenů do bakteriálního rodu Pseudomonas. Výsledky biochemické charakterizace na základě BIOLOG MicroStation systému umožnilo identifikaci 3 kmenů jako Pseudomonas fluorescens, 2 kmenů jako Pseudomonas putida a 1 kmene jako Pseudomonas aeruginosa. Při srovnání nově izolovaných kmenů s dosud publikovanými studiemi pro jednotlivé bakteriální kmeny byly vysvětleny rozdíly v jejich biochemické aktivitě, které jsou dány do souvislosti se schopností adaptace mikroorganismů na podmínky znečištěného prostředí. Z hlediska taxonomického řazení mohou vést výsledky této studie $\mathrm{k}$ budoucí reklasifikaci do různých biotypů $\mathrm{v}$ rámci daného bakteriálního druhu. 